\title{
Elsőként kutatta a ma 250 éves magyar orvosi kar történetét - Kátai Gábor (1831-1878)
}

\author{
Kiss László dr.
}

A 2019-es év legjelesebb orvostörténeti évfordulója az első magyar orvosi kar megalapítása Nagyszombatban (ma: Trnava, Szlovákia) 1769-ben. A Pázmány Péter által 1635-ben alapított, ekkor még nem teljes jezsuita egyetemet Mária Terézia orvosi karral bővítve tette teljessé. A hazai orvosképzés históriáját - a nagyszombati kart megelőző századoktól kezdve -, a Nagyszombatban megindult hazai képzés történetét a Schultheisz Emil és Magyar László András által szerkesztett szakmunka tárgyalja [1]. A szakmunka - korabeli dokumentumok többnyire első, illetve a témáról írt szakdolgozatok újraközlésével - a nagyszombati orvosi kar történetének legteljesebb és leghitelesebb feldolgozása.

Nos, e méltatás után eretnekségnek tưnhet azon állításunk, hogy a szerkesztők teljességre való törekvése ellenére kimaradt a kötetből egy fontos tanulmány. Számunkra e tanulmány speciális értékét az adja, hogy a legrégibb, máig folyamatosan megjelenő periodikum, az Orvosi Hetilap hasábjain jelent meg 1860-ban [2] - szerzője egy medikus, Kátai Gábor volt! (Ezért nem szerepel a szerző neve elött a dr. jelzés.)

Mielőtt bárki is könnyelműséggel vádolná Markusovszky Lajost, a lap szerkesztőjét, sietünk leszögezni: nem akármilyen medikusnak adott teret Magyarország akkoriban egyetlen magyar nyelvü orvosi lapjában. A 26 éves Kátai ekkor már „okleveles gyógyszerész” - oklevelét Bécsben szerezte meg -, sôt medikusi tanulmányai költségeit is maga teremtette elő Matta László pesti gyógyszertárában vállalt „mellékállásával” [3]. Másodéves pesti medikus, amikor 1857-ben megindul az Orvosi Hetilap. Az „okl. gyógyszerész” Kátai a lap 27. és 28. számában mutatkozik be „Gyógyszertani szemelvények... Gyógyszerészet tudományos állása hazánkban és annak legsürgősb teendői" című kétrészes dolgozatával. A későbbi évfolyamokban is számos „gyógyszerismei”, „gyógyszertani” közleménye jelenik meg. Söt 1860-ban a lap szerkesztői - Markusovszky és Poor Imre - a lap IV. évfolyamának „előrajzában” öt nevezik meg „a gyógyszertanra és gyógyszerészetre" figyelő „ügytársnak”. (Kollégája e tevékenységben Wágner János egyetemi tanár, az Orvosegylet elnöke.) Az 1862-ben induló Gyógyszerészi Hetilap megjelenéséig Kátainak az Orvosi Hetilapban közölt lapszemléi, recenziói voltak a gyógy- szerészek szakmai továbbképzésének fó eszközei. A gyógyszerészeti szakirodalom Kátait tekinti a magyar gyógyszerészképzés és a gyógyszerészeti irodalom megújítójának [4].

Kátai érdeklődése az orvostörténelem iránt már első írásai közt tetten érhető. Az Orvosi Hetilap 7. száma 1859-ben közli a „Dr. Csorba József emlékezete” című írását. Ebben azt az 1858. november 23-án elhunyt Csorba doktort méltatja, aki 1817 és 1848 között Somogy vármegye főorvosa volt. Írásának értékét, időállóságát bizonyítja az a tény, hogy most említett dolgozata első helyen szerepel a Magyar Orvoséletrajzi Lexikon Csorba-szócikkének irodalmi hivatkozásai közt [5].

Meggyőződésem, hogy az utókor hasonló figyelmét érdemli meg a bevezetőben említett „egyetemtörténete” is. Sajnos az orvostörténész „utód” a Kátai halálának centenáriumán, 1978-ban írt dolgozatában nem szentelt kellő figyelmet elődje „történeti tanulmányának”, bár megjegyzi, hogy Kátait e cikke „Győry Tibor kartörténetíró és bibliográfus ôsévé avatja" [3]. Ezt a mulasztást 1989-ben az Orvosi Hetilap mérsékelte, ezt írva: „Az 1860-as években jelentkezett orvostörténészek közül kiemelkedik Kátai Gábor (1831-1878), aki elsőnek kísérelte meg összeállítani a pesti egyetem orvosi karának történetét..." [6].

A „kísérletre” - mint jeleztük - az Orvosi Hetilap hasábjain került sor 1860-ban. A Vörösmarty-mottóval "Hass, alkoss, gyarapíts, s a haza fényre derül” - induló „Tárcza” a következő részekből áll: I. (A veszprémi, pécsi, ó-budai és posonyi(!) egyetemek és a budai fóiskola), II. A Pázmány-féle nagyszombati egyetem, II. (!) A Pázmány-féle nagyszombati egyetem (Folytatás), III. A budavári (1777-1784) és pesti (1784-1860) egyetem, III. (!) A budavári (1777-1784) és pesti (1784-1860) egyetem (Folyt.) A dolgozathoz nincs csatolva külön irodalom, ám a számtalan lábjegyzetből kiolvasható, milyen forrásokból dolgozott Kátai. Közreadjuk a források - általunk ábécérendbe szorított - listáját, hiszen ez egyben azt is jelzi, hol állt 1860-ban a történettudomány a „magyar egyetemi ügy" históriáját illetően:

- Belnay Georgius: Historia literarum bonarumque artium in Hungaria. 1799. [Pozsony] 
- Corpus Juris Hungarici. Tomus Secundus, Budae, 1779.

- Fejér, Georgius: Historia Academiae Scientiarum Pazmaniae archiepiscopalis ac M. Theresianae regiae literaria. Budae, 1835.

- Ferenczy Zsigmond Jakab: Magyar irodalom és tudományosság története. Pest, 1854.

- Katona: Hist Crit Reg Hung. T. XXXI. [I-XLII., 1779-1817, Pest]

- Kazy Franciscus: Historia Universitatis Societatis Jesu... ad annum Christi 1735. Tyrnaviae, 1737.

- Koller [József]: Hist. Episcop. Quinqueeccl. [I-IV., Pozsony, 1782-1812]

- Linzbauer Ferenc: Codex Sanitario-Medicinalis Hungariae. [I-III., Buda, 1852-1861]

- Miller de Brassó, Jac. Ferd. Epistolae S.R.E. Cardinalis archiepiscopi Strigoniensis et Hungariae Primatis Petri Pázmány ad Pontificies, Imperatores, Reges, Principes Cardinales etc. Budae, 1822.

- Palatini Regni Hungariae diversis criptoribus a primis temporibus ad nostram usque aetatem etc. Editio tertia. Tyrnaviae, 1760.

- Péczely József: A magyarok történetei. Debrecen, 1837.

- Pray: Specim. Hierarch. Hung. Part. I. [I-II., Pozsony és Kassa, 1776-1779]

- Sermo dum regia universitatis hungarica bissecularem memoriam natalium suorum a Petro Pazman etc. Tyrnaviae - acceptorum ritu solemni - celebratet. Budae, 1836.

- Schier Xystus: Memoria Academiae Istropolitanae seu Posoniensis. Vindob, 1774.

- Toldy Ferenc: A magyar nemzeti irodalom története. Pest, 1851, II. kötet.

- Vállas Antal: Nemzeti encyclopaedia. Pest, 1848.

- Wallaszky Pál: Conspectus Reipublicae literariae in Hungaria. Posonii et Lipsiae, 1785.

Kátai így fogalmazta meg dolgozata célját: „A történetírást kell megkérdeznünk avégett, hogy megtudhassuk, minő pártoltatásban részesültek nálunk a tudományok régibb időkben, s hogy megláthassuk, kik, mikor és mennyit tettek azoknak előmozdítására többen fejedelmeink s nevezetesebb hazánkfiai közől; a múlt kárpitját kell ez okból szellőztetnünk, mit mi örömest teszünk, mert jelen értekezésünk feladatául egyenesen azt tűzők ki” [2: 177].

Nincs terünk a dolgozat részletes - a nagyszombati egyetem előtti történésekre is kitérő - elemzésére, ezért csak az orvosi karhoz kötődő és Kátai által először közölt részletekre hívjuk fel a figyelmet. Kátai volt az első, aki magyar nyelvre fordította Mária Terézia 1769. december 15-én kelt rendeletét [2: 418-419] - így értékelve azt: „ez az, melyhez minden figyelmünknek hozzá kell tapadnia azért, mert egyetemünk orvosi karának ez a kezdőbetúje". (A rendelet szövegének teljes, új fordítását Magyar László András készíti majd el 2005-ben [1].) Mária Terézia 1780-ban, trónra lépésének 40. évfordu- lóján adta ki az egyetem alapítványi oklevelét (Diploma inaugurale). Ezzel kapcsolatban Kátai megjegyzi: „ha ezen alapítvány-levél célját bárha csak a mai napig is úgy elérhette s betölthette volna, mint ahogy az írva van: Mária Terézia királyné diademjának nem a kollini ${ }^{1}$ híres győzelem, nem is az ennek következtében felállított katonai Terézrend alapítása, de a magyar királyi tudományos egyetem újjászervezése és felvirágzása képezendette legragyogóbb boglárát” [2: 421].

Érdemes tallózni Kátainak a II. József uralkodása (1780-1790) idejéhez fűződő „kisded vázlatocskájából”. „Kalapos királyunk” 1784-ben terjedelmes „mandatumot" küldött a Pozsonyból Budára költöztetett (magyar) Helytartótanácshoz. Ennek alapján a Helytartótanács június 14-én rendeletet adott ki, melynek több pontja az orvosi kart, illetve annak medikusait is érintette: az ifjúságnak megengedik színházba, táncmulatságra menni, „föltéve, hogy semmi erkölcsrontó jeleneteket nem szabad látniok". A tanárok rendkívüli előadásokat is tarthatnak. „Mivel tudva van, hogy többen vannak... az orvosi és bölcsészi karnál, kik külföldi egyetemeken megfordultak, ezeket szorgalmazni kell, hogy külföldi tudós barátjaikkal az érintkezést fenntartsák és iparkodjanak egy tudós társaság alapjait megvetni..." [2: 593]. 1784 novemberétôl tandíjat vezetnek be: a sebészeti tudományok hallgatásáért évi 18, a többi „magasabb tudományok karaiban” évi 50 forintot. Érdemes idézni Kátai sommás véleményét II. József reformjairól: „...reformjainak roppant épülete a légbe volt építve, egyetlen oszlopa ő maga volt, az oszlop kidúltével össze kellett omlania magának az épületnek is" [2: 594]. Csupán a teljesség kedvéért: a színházba, mulatságra járást 1802-ben újra megtiltják.

Kátai szerint két kórházalapítás - „klinika”? - is történik II. József idejében: 1786. június 7-én a klarissza szüzek zárdájából városi kórház lesz, és a belgyógyászati tanár ${ }^{2}$ „utasítaték előadásai tartására és a gyakorlati kezelés életbehozására”. 1786. augusztus 16-án 16 betegre és 4 „üdülőre” sebészi kórházat alapítanak oly módon, hogy „a szükséges felszerelésre egyszer mindenkorra $1308 \mathrm{ft}$ $33 \mathrm{kr}$, betegápolásra pedig évente $3115 \mathrm{ft}$ utalványoztatott az egyetem alapjából” [2: 595]. Sajnos Kátai nem közli e kórházak további sorsát. A budapesti kórházak történetét feldolgozó monográfia csak a gyógyító rendek kórházairól tesz említést [7]. Valószínü, hogy múködésük 1798-ban szûnt meg, a 220 betegágyas Szent Rókus Kórház megnyitásával.

A Hőgyes-féle millenniumi Emlékkönyvben Kétli Károly írta meg a belgyógyászati oktatás történetét, de nem említi a klarisszák zárdájában való múködést: „....az orvosi kar Pestre tétetett át, éspedig a hatvani (jelenleg Kossuth) és újvilág-utca sarkán létezett klastromi ${ }^{3}$ épü-

\footnotetext{
1757-ben az osztrákok Kolínnál (Csehország) vívtak győztes csatát a poroszokkal - ennek emlékére alapította a császárnő a Mária Terézia-rendet. 2 Ez idő tájt: Trnka Vencel.

A „klastrom” a feloszlatott jezsuita rendé volt, az Újvilág utca ma Semmelweis nevét viseli.
} 
letbe" [8: 573]. A klarissza apácák történetét is közreadó „történelmi kalauz” sem tud a zárda - mely az egyetemi templom mögött, a Szerb utca és a Királyi Pál utca sarkán állt - kórházi múködéséről: „II. József feloszlató rendeletét 1782. ápr. 10-én hirdették ki... A kolostorban rövid ideig papnevelő szeminárium múködött, később zálogháznak használták" [9: 549]. Kovács József a sebészeti oktatás történetét vázolva ezt állítja: „1784-ben Pestre történvén az áthelyezés, a gyakorlati oktatás az első időben a közkórházban tartatott, majd a hatvani utcában" [8: 550]. Érdemes felfigyelni a Kátai által „üdülők”-nek nevezett kórházlakókra. A pozsonyi irgalmas kórháznak 1802-től lesz majd egy „Rekonvaleszenthaus" nevű részlege, amely a betegségből (mütétből?) való felüdülést, felépülést (rekonvaleszcenciát) segítette elő [10]. Valószínű, hogy a Kátai által említett „üdülő” részleg tekinthető a rehabilitációs orvostan első magyar fecskéjének.

Kátai egyetemtörténeti tanulmányának utolsó része 1860 nyarán, az Orvosi Hetilap 30. számában jelent meg. Zárszavában óvatosan utal az 1848/49-es eseményekre: „Az idő meg nem állapítható (!) kereke széttiporta e szép reményeket" - értsd: az egyetem reformjának terveit -, ám mégis optimistán hiszi, hogy „a magyar királyi egyetem ez időszerinti közbizodalomnak és tiszteletnek örvendő igazgatósága az egyetem jóllétét és fényét előmozdítani, jogait - ha kell - minden időben és bárki ellen védelmezni körömszakadásig meg nem szünend" [2: 596]. Nos, Kátai optimizmusát csak rövid időre igazolta az „idő kereke”: az 1848-as törvények alapján visszaállított „magyar éra”, amely számára meghozta a „nagykúnkerületi fóorvosi” állást, csak egy évig tartott - beköszöntött a „provizorium”. Kátai lemondott foorvosi tisztségéről, és egy nyugat-európai tanulmányúttal vigasztalódott.

Éltének további folyása jól ismert - előbb Karcagon gyakorló orvos 1865-ig, pár évig Pesten a Természettudományi Társulat első titkára (megírja a Társulat történetét) -, majd 1868-tól haláláig újra a „nagy-kunok” föorvosa Karcagon [3]. Nem lesz hütlen sem az Orvosi Hetilaphoz, sem az orvostörténelemhez. A magyar orvosok és természetvizsgálók 1874-ben Győrött tartott vándorgyưlésén felolvasta „Az orvosi tudomány jelen iránya" címú írását, melyet az orvostörténész „sűrített orvostörténeti tanulmányként" értékel [3].

Az Orvosi Hetilap mint egykori szorgalmas munkatársának és a magyar orvoskari történet első kutatójának emléke előtt tiszteleg a nagyszombati kar alapításának 250. évfordulóján.

\section{Irodalom}

[1] Schultheisz E, Magyar LA. (ed.) Medical education at university in Nagyszombat (Trnava). [Orvosképzés a nagyszombati egyetemen.] Magyar Tudománytörténeti Intézet, Piliscsaba, 2005. [Hungarian]

[2] Kátai G. Historical study about university in Hungary with special attention to medical university and literature in Hungary from the beginning to nowadays. [Történeti tanulmány a magyar egyetemi ügy körül, különös tekintettel a magyar orvosi egyetemre és irodalomra, a legrégibb időktôl máig.] Orv Hetil. 1860; 4: 175-181, 255-262, 413-421, 575-581, 591-596. [Hungarian]

[3] Szállási Á. Gábor Kátai died a hundred years ago. [Száz esztendeje halt meg Kátai Gábor.] Orv Hetil. 1978; 119: 595-598. [Hungarian]

[4] Szalay E. The scholar of Karcag - Gábor Kátai (1831-1878). [A karcagi tudós - Kátai Gábor (1831-1878).] Gyógyszerészettörténet 2004; 2: 24-25. [Hungarian]

[5] Kapronczay K. Hungarian medical biographical encyclopaedia. [Magyar orvoséletrajzi lexikon.] Mundus Magyar Egyetemi Kiadó, Budapest, 2004. [Hungarian]

[6] Kapronczay K. The forgotten historians of medicine from last century. [Elfeledett orvostörténészeink a múlt századból.] Orv Hetil. 1989; 130: 2051-2052. [Hungarian]

[7] Kapronczay K. The medicinal Budapest. [Gyógyító Budapest.] Holnap Kiadó, Budapest, 2011. [Hungarian]

[8] Hoggyes E. (ed.): Memory book of the past and present of the Medical Faculty of Royal Hungarian University of Budapest. [Emlékkönyv a Budapesti Királyi Magyar Tudomány Egyetem Orvosi Karának múltjáról és jelenéről.] Magyar Orvosi Könyvkiadó Társulat, Budapest, 1896. [Hungarian]

[9] Puskely M. Christian monasticism. Historical guide I. [Keresztény szerzetesség. Történelmi kalauz I.] Bencés Kiadó, Budapest, 1995. [Hungarian]

[10] Kiss L. The history of the hospitals of the Brothers of Mercy in the territory of modern era Slovakia until 1867. [Az irgalmas rendi kórházak története a mai Szlovákia területén 1867-ig]. Via Socialis 2016; 2: 57-76. [Hungarian]

(Kiss László dr., SK-93 008 Csilizradvány 284., Szlovákia e-mail: kiss.agi@panelnet.sk)

\section{A rendezvények és kongresszusok híranyagának leadása}

a lap megjelenése előtt legalább 40 nappal lehetséges, a 6 hetes nyomdai átfutás miatt. Kérjük megrendelőink szíves megértését.

A híranyagokat a következő címre kérjük:

Orvosi Hetilap titkársága: edit.budai@akademiai.hu

Akadémiai Kiadó Zrt. 